\title{
Pine Needle Oil (Pinus Sylvestris)
}

National Cancer Institute

\section{Source}

National Cancer Institute. Pine Needle Oil (Pinus Sylvestris). NCI Thesaurus. Code C84061.

The essential oil extracted from the needles and twigs of Pinus sylvestris. Pine oil is used for aromatherapy and for its antiseptic qualities in soaps and cleaning products. 